\title{
PERKEMBANGAN PENDIDIKAN AGAMA ISLAM DI SEKOLAH DASAR TAHUN 1945-1966
}

\author{
Luthfi Khairul Fikri, ${ }^{*}$ \\ Munawar Rahmat, Wahyu Wibisana \\ Program Studi Ilmu Pendidikan Agama Islam, \\ Fakultas Pendidikan Ilmu Pengetahuan Sosial, Universitas Pendidikan Indonesia \\ *Email: luthfikaef@gmail.com
}

\begin{abstract}
ABSTRAK
Pendidikan agama dewasa ini merupakan bagian dari kurikulum wajib yang diselenggarakan di sekolah umum pada semua jenjang dan jenis pendidikan. Sebelumnya pada masa penjajahan Belanda, pendidikan agama tidak begitu diperhatikan bahkan cenderung diawasi kegiatannya. Sejak awal kemerdekaan dan selama masa Orde Lama, pengakuan tentang eksistensi pendidikan agama di sekolah umum mulai timbul, meskipun dalam prakteknya perkembangan PAI pada kurun waktu tersebut senantiasa menghadapi kendala. Oleh karena itu, pertanyaan utama dari penelitian ini adalah bagaimana Perkembangan Pendidikan Agama Islam di sekolah Dasar pada Tahun 1945-1966. Metode yang digunakan dalam penelitian ini menggunakan pendekatan kualitatif. Data-data yang disiapkan dalam penelitian ini adalah yang bersumber dari literatur atau menggunakan cara library research. Hasil penelitian menunjukkan bahwa pendidikan Indonesia setelah kemerdekaan mengalami perubahan. Pemerintah ingin membuat sistem pendidikan nasional yang sesuai dengan keadaan rakyat Indonesia. Perubahan yang terjadi terutama dalam landasan idiilnya, tujuan pendidikan, sistem persekolahan dan kesempatan belajar yang diberikan kepada rakyat Indonesia. Kemajuan yang paling menonjol adalah dalam masalah pendidikan agama. Pengajaran Agama, khususnya Pengajaran Agama Islam dirasakan penting untuk dimasukkan ke dalam rencana pengajaran dalam pendidikan nasional. Hal ini dikarenakan pendidikan agama sesuai dengan landasan negara yang berdasarkan Ketuhanan Yang Maha Esa. Pada perkembangan selanjutnya pemerintah mengeluarkan kebijakan-kebijakan tentang pendidikan agama yang merupakan bentuk pengakuan resmi negara terhadap pendidikan agama dalam sistem pendidikan nasional.
\end{abstract}

Kata Kunci: Pendidikan Nasional, Pendidikan Agama, Sekolah Dasar

TARBAWY, Vol. 1, Nomor 1, (2014)|44 


\section{PENDAHULUAN}

Pendidikan adalah suatu aktivitas untuk mengembangkan seluruh aspek kepribadian manusia yang berjalan seumur hidup. Dengan kata lain pendidikan tidak hanya berlangsung di dalam kelas. Pendidikan bukan bersifat formal saja, tetapi mencakup pula yang nonformal.

Secara umum pendidikan dapat diartikan sebagai usaha manusia untuk membina kepribadiannya sesuai dengan nilai-nilai di dalam masyarakat dan kebudayaan. Oleh karena itu, bagaimana pun sederhananya peradaban suatu masyarakat, di dalamnya terjadi atau berlangsung suatu proses pendidikan. Oleh karena itu, sering dinyatakan pendidikan telah ada sepanjang peradaban umat manusia. Pendidikan pada hakikatnya merupakan usaha manusia melestarikan hidupnya (Tim Dosen FKIP Malang dalam Zuhairini, 2008, hlm. 150).

Islam adalah agama yang menempatkan pendidikan dalam posisi yang sangat vital. Bukanlah sesuatu yang kebetulan jika lima ayat pertama yang diwahyukan Allah kepada Nabi Muhammad, dalam surat al-'Alaq, dimulai dengan perintah membaca, iqra'. Selain itu, pesan-pesan al-Qur'an dalam hubungannya dengan pendidikan pun dapat dijumpai dalam berbagai ayat dan surat dengan aneka ungkapan pernyataan, pertanyaan, dan kisah. Rahim (2001, hlm. 4) menjelaskan, kata 'ilm dan derivasinya digunakan paling dominan dalam al-Qur'an untuk menunjukkan perhatian Islam yang luar biasa terhadap pendidikan. Untuk menegaskan kenyataan di atas, Isma'il Raji al-Faruqi (dalam Rahim, 2001, hlm. 4), membuat pernyataan bahwa "Islam mengidentifikasi dirinya sendiri dengan ilmu. Bagi Islam, ilmu adalah syarat dan sekaligus tujuan dari agama ini".

Berbicara tentang pendidikan Islam di Indonesia, sangatlah erat hubungannya dengan kedatangan Islam itu sendiri ke Indonesia. Dalam konteks ini Mahmud Yunus (dalam Nizar, 2009, hlm. 341) mengatakan, bahwa sejarah pendidikan Islam sama tuanya dengan masuknya Islam ke Indonesia. Hal ini disebabkan karena pemeluk agama tersebut sudah barang tentu ingin mempelajari dan mengetahui lebih mendalami tentang ajaran-ajaran Islam. Ingin pandai shalat, berdoa, dan membaca Al-Quran yang menyebabkan timbulnya proses belajar, meskipun dalam pengertian yang amat sederhana. Dari sinilah mulai timbul pendidikan agama Islam, di mana pada mulanya mereka belajar di rumahrumah, langgar/surau, masjid dan kemudian berkembang menjadi pondok pesantren. Setelah itu baru timbul sistem madrasah yang teratur sebagaimana yang kita kenal sekarang ini.

Sejak awal kemerdekaan dan selama masa Orde Lama, pengakuan tentang eksistensi pendidikan agama di sekolah umum mulai timbul, meskipun dalam prakteknya perkembangan PAI pada kurun waktu tersebut senantiasa menghadapi kendala politis maupun non-politis. Kendala yang bersifat politis ialah berkaitan dengan ketentuan perundangan yang cenderung kurang memberikan ruang peran bagi pendidikan agama, bahkan tidak mengakomodir keberadaan pendidikan agama tersebut di sekolah-sekolah umum. Sebab pendidikan agama dipandang sebagai urusan individu dan bukan menjadi tanggung jawab lembaga pendidikan (sekolah). Sedang kendala non-politis berkaitan dengan keadaan sosial-budaya maupun keterbatasan-keterbatasan sumber PAI itu sendiri, baik kurikulum, guru maupun metode pembelajaran.

Pada tahun 1818 keluarlah peraturan Pemerintah, yang memuat peraturan umum mengenai persekolahan dan sekolah rendah. Isinya hanya berupa ketentuanketentuan mengenai pengawasan, sedikit mengenai penyelenggaraan pengajaran dan tidak menyinggung sedikit pun mengenai perluasan pengajaran di kalangan bangsa Indonesia. Hal-hal yang diperhatikan hanya penyelenggaraan sekolah-sekolah rendah 
bagi bangsa Belanda. Menurut peraturan itu di sekolah rendah diberikan pengajaran membaca, menulis, berhitung, bahasa Belanda, sejarah dan ilmu bumi. (Djumhur, 1976, hlm. 121)

Pada tahun 1863 dan 1864 Pemerintah mulai menjalankan politik pengajaran liberal. Maka tujuan sekolah bukan lagi mendidik calon-calon pegawai, tetapi mendidik rakyat dalam arti yang umum. Pengajaran harusnya membawa rakyat kepada arah kebahagiaan, sehingga karenanya negeri Belanda menjadi tambah subur dan makmur. (Djumhur, 1976, hlm. 127)

Isi rencana pelajaran pada sekolah ini disesuaikan dengan keharusan sekolah untuk mendidik calon-calon pegawai. Karena di lapangan para pegawai Bumiputera diharuskan bisa berbicara bahasa Melayu, yang ketika itu dipakai sebagai bahasa resmi, maka selain diajarkan bahasa daerah diajarkan juga bahas Melayu. Pelajaran lain yang diajarkan adalah mata pelajaran mengukur tanah.

Perkembangan pendidikan dan pengajaran sampai akhir abad ke-19 di Hindia Belanda memperlihatkan kecenderungan yang dipengaruhi oleh politik pendidikan pada khususnya dan politik kebudayaan pada umumnya. Pertama, kecenderungan yang dipengaruhi oleh aliran liberalisme yang masih kuat di negeri Belanda, di mana pemerintah harus bersifat netral dalam bidang pengajaran, artinya tidak di atas aliran agama tertentu dan oleh sebab itu pengajaran agama tidak diberikan. Kedua, kecenderungan yang dipengaruhi oleh politik bahasa dalam kerangka politik kebudayaan.

\section{METODE}

Desain penelitian ini menggunakan pendekatan kualitatif. Pendekatan kualitatif desainnya bersifat umum, dan berubahubah atau berkembang sesuai dengan situasi di lapangan. Sebagaimana yang dijelaskan oleh Sugiyono (2011, hlm. 12) bahwa "metode ini disebut juga metode interpretive karena data hasil penelitian lebih berkenaan dengan interpretasi tarhadap data yang ditemukan di lapangan". Selanjutnya Putra dan Lisnawati (2012, hlm. 28) menyebutkan "desain penelitian kualitatif biasanya bersifat global, tidak terperinci, tidak pasti dan sangat fleksibel". Dengan demikian desain hanya digunakan sebagai asumsi untuk melakukan penelitian, oleh karena itu desain penelitian kualitatif bersifat fleksibel dan terbuka.

Arikunto (2010, hlm. 203) menerangkan bahwa metode penelitian adalah "cara yang digunakan oleh peneliti dalam mengumpulkan data penelitiannya", sedangkan Alwasilah (2009, hlm. 149) mengungkapkan bahwa, "metode penelitian merupakan alat atau cara untuk menjawab pertanyaan penelitian". Dengan demikian metode penelitian merupakan cara atau alat yang digunakan oleh peneliti untuk menjawab serangkaian pertanyaan yang dirumuskan dalam rumusan masalah.

1. Metode Deskriptif

Dalam penelitian ini peneliti menggunakan metode deskriptif serta mengumpulkan data- data yang berkaitan dengan perkembangan PAI di sekolah umum. Penelitian ini dikategorikan sebagai penelitian deskriptif, karena pendekatan yang dilakukan adalah melalui pendekatan kualitatif. Arikunto (2010, hlm. 151)

\section{Studi Literatur}

Teknik pengumpulan data yang digunakan penulis selama proses penelitian yaitu studi literatur, teknik ini digunakan dalam upaya mengumpulkan berbagai informasi yang tekat dengan masalah penelitian yang dikaji, studi literatur, teknik ini dilakukan dengan mengumpulkan sumber-sumber berupa buku yang relevan dengan permasalahan dan dimaksudkan untuk memperoleh data yang dapat menunjang penelitian.

$$
\text { Sugiyono (2011, hlm. }
$$
menjelaskan sebagai alat instrumen, "peneliti harus memiliki bekal teori dan 
wawasan yang luas sehingga mampu bertanya, menganalisis, memotret, dan mengkontruksi situasi sosial yang diteliti menjadi lebih jelas dan bermakna". Dengan kata lain peneliti menjadi instrumen utama penelitian. Maka dalam penelitian ini, peneliti bertindak sebagai perencana, pelaksana pengumpul data yang kemudian menginterpretasi data yang telah terkumpul.

Dalam melakukan penelitian, peneliti menggunakan studi kepustakaan. Sarwono (2006. hlm. 49) menjelaskan beberapa sumber kepustakaan yang dapat digunakan oleh peneliti di antaranya "abstrak, hasil penelitian, indeks, review, jurnal, buku referensi", sedangkan data adalah keterangan mengenai variabel pada se-jumlah objek (Purwanto, 2007, hlm. 192).

Adapun untuk data-data yang disiapkan dalam penelitian ini adalah yang bersumber dari literatur atau menggunakan cara library research dengan tujuan untuk mengumpulkan data informasi dengan bantuan bermacam-macam material yang terdapat di ruang perpustakaan. Penelitian studi kepustakaan ini dilaksanakan di perpustakaan. Sebagaimana yang dijelaskan oleh Sukardi (2004, hlm. 35) perpustakaan merupakan tempat yang ideal, karena di perpustakaan penelitian akan mudah mengakses bermacam-macam sumber yang relevan

\section{HASIL DAN PEMBAHASAN}

Setelah Proklamasi Kemerdekaan Indonesia tanggal 17 Agustus 1945, terjadi perubahan dalam bidang pendidikan. Perubahan yang dilakukan cukup mendasar, yaitu menyangkut penyesuaian dasar dan tujuan pendidikan, sistem persekolahan, dan isi pendidikan sesuai dengan aspirasi bangsa dan negara merdeka untuk memberikan kesempatan belajar seluas-luasnya kepada rakyat Indonesia. (Djojonegoro, 1996, hlm. 72)

Pada tanggal 29 Desember 1945 Badan Pekerja Komite Nasional Indonesia
Pusat (BPKNIP) mengusulkan kepada Kementerian Pendidikan, Pengajaran, dan Kebudayaan (PP dan K) agar secepat mungkin mengusahakan pembaharuan pendidikan dan pengajaran sesuai dengan rencana pokok pendidikan baru. (Djojonegoro, 1996, hlm. 73)

Poin-poin dalam usulan tersebut berisi tentang perubahan pedoman pendidikan dan pengajaran, metode, pengajaran tinggi, pengajaran agama, pemberian bantuan kepada madrasah dan pesantren, pengajaran teknik dan ekonomi, pengajaran kesehatan. Selain itu, diatur juga sistem pembayaran mulai dari sekolah rendah, menengah dan tinggi sehingga rakyat yang kurang mampu masih bisa mengenyam pendidikan.

Salah satu poin penting dalam usulan tersebut adalah tentang pengajaran agama di sekolah. Pada poin d disebutkan bahwa Pengajaran agama hendaknya mendapat tempat yang sesuai dan mendapat perhatian yang semestinya, dengan tidak mengurangi kemerdekaan golongangolongan yang berkehendak mengikuti kepercayaan yang dianut. Tentang cara pelaksanaannya, kementerian perlu mengadakan pe-rundingan dengan Badan Pekerja KNIP.

Atas usul Badan Pekerja KNIP, Menteri PP dan K (Mr. Soewandi) membuat surat Keputusan tanggal 1 Maret 1946 No.104/Bhg.0, untuk membentuk Panitia Penyelidik Pengajaran RI di bawah pimpinan Ki Hajar Dewantara yang dibantu oleh seorang penulis Soegarda Poerbakawatja. Tugas yang dibebankan kepada panitia ini, antara lain (Djojonegoro, 1996, hlm. 75):

1. merencanakan susunan baru dari tiap-tiap jenis sekolah ;

2. menetapkan bahan-bahan pengajaran dengan memperhatikan keperluan yang praktis dan tidak terlalu berat; dan

3. menyiapkan rencana-rencana pelajaran untuk tiap-tiap sekolah dan tiap-tiap kelas. 
Kesungguhan pemerintah terhadap pendidikan itu terlihat setelah dibentuknya Undang-Undang Pokok Pendidikan dan Pengajaran, membentuk Panitia Penyelidik Pendidikan dan Pengajaran pada tahun 1946 yang dipimpin oleh $\mathrm{Ki}$ Hajar Dewantara (Ahmadi, 2003, hlm. 31).

Panitia ini mengadakan Kongres Pendidikan Indonesia di Solo pada tanggal 4 sampai tanggal 7 bulan Maret 1947 di bawah pimpinan Prof. Sunarya Kalapaking. Maksud kongres itu bertujuan untuk meninjau kembali berbagai masalah kependidikan nasional (Djumhur, 1976 hlm. 202).

Pada tahun 1948 Menteri PP dan K (Mr. Ali Sastroamidjodjo), menganggap perlu untuk membentuk "Panitia Pembentukan Rencana Undang-Undang Pokok Pendidikan dan Pengajaran". Panitia itu diketuai oleh Ki Hajar Dewantara dan diberikan tugas untuk menyusun Rencana Undang-Undang Pokok Pendidikan dan Pengajaran di sekolah. Panitia bekerja dengan memperhatikan hasil-hasil pekerjaan. Panitia-panitia terdahulu dan Kongres Pendidikan di Solo (Djumhur, 1976 hlm. 203).

Tahun 1949 diadakan Kongres Pendidikan kedua di Yogyakarta. Dengan selesainya kongres pendidikan di Yogyakarta, maka bertambah banyaklah bahan-bahan masukan guna menyusun Undang-Undang Pokok Pendidikan (Daulay, 2007, hlm. 85).

Pada bulan Desember 1949, Republik Indonesia mengalami perubahan ke-tatanegaraan. Undang-Undang Dasar 1945 diganti dengan Konstitusi Sementara Republik Indonesia Serikat. Walaupun dasar pendidikan tidak mengalami perubahan, tetapi tujuan pendidikannya mengalami perubahan.

Akhirnya pada tanggal 2 April tahun 1950 lahirlah Undang-undang No. 4 Tahun 1950 mengenai Dasar-Dasar Pendidikan dan Pengajaran di Sekolah oleh Presiden Republik Indonesia dan Menteri Pendidikan, Pengajaran, dan Kebudayaan, dengan nama Undang-Undang tentang
Dasar Pendidikan dan Pengajaran di Sekolah yang disingkat menjadi UUPP untuk kemudian diundangkan pada tanggal 5 April 1950 oleh Menteri Kehakiman A.G. Pringgodigdo. Undang-undang ini seluruhnya terdiri dari 17 bab dan 30 pasal. Di dalam UUPP tersebut dicantumkan tujuan dan dasar-dasar pendidikan dan pengajaran (Djojonegoro, 1996, hlm. 76).

Sebagai hasil dari berbagai usaha yang telah disebutkan di atas, sistem pendidikan di Indonesia setelah masa kemerdekaan mengalami berbagai perubahan. Salah satu bentuk perubahan tersebut menyangkut pula sistem persekolahan. Sistem persekolahan yang berlaku sejak tahun 1945 sampai 1950 meliputi pendidikan rendah, pendidikan guru, umum, kejuruan, dan pendidikan tinggi.

Pendidikan Rendah adalah pendidikan sekolah dasar yang sejak awal kemerdekaan disebut Sekolah Rakyat (SR). Lama pendidikan yang semula tiga tahun diubah menjadi enam tahun. Maksud pendirian SR adalah untuk meningkatkan taraf pendidikan dan menampung hasrat yang besar dari mereka yang ingin bersekolah. (Djojonegoro, 1996, hlm. 77)

Sejak awal kemerdekaan, harapan dan perjuangan umat Islam untuk memajukan pendidikan Agama Islam di sekolah umum mulai mendapatkan momentumnya. Pendidikan agama Islam untuk umum mulai diatur secara resmi oleh pemerintah pada bulan Desember 1946. sebelum itu pendidikan agama sebagai ganti pendidikan budi pekerti yang sudah ada sejak zaman Jepang, berjalan sendirisendiri di masing-masing daerah (Ashari, 2015).

Di tengah-tengah berkobarnya revolusi fisik, pemerintah RI tetap membina pendidikan agama. Pendidikan Pendidikan Agama tersebut secara formal institusional dipercayakan kepada Departemen Agama dan Departemen Pendidikan dan Kebudayaan. Oleh karena itu dikeluarkanlah peraturan-peraturan bersama antara kedua Departemen tersebut 
untuk mengelola pendidikan agama di sekolah-sekolah umum baik negeri maupun swasta.

Upaya untuk memasukkan pendidikan agama Islam sebagai mata pelajaran di sekolah umum yang pernah dilakukan dan selalu gagal terus dilakukan. Pengakuan akan urgensi pendidikan agama di sekolah dimulai dengan usulan BP-KNIP pada tanggal 27 Desember 1945 dalam rapatnya memutuskan pula antara lain:

a. Pengajaran agama hendaknya mendapat tempat yang teratur, saksama, hingga cukup mendapat perhatian yang semestinya, dengan tidak mengurangi kemerdekaan golongan-golongan yang berkehendak mengikuti kepercayaan yang dipilihnya. Tentang cara melakukan ini baiklah kementerian mengadakan perundingan dengan badan pekerja.

b. Madrasah dan pesantren-pesantren yang pada hakikatnya alah satu alat sumber pendidikan dan pencerdasan rakyat jelata yang sudah berurat berkar dalam masyarakat Indonesia umumnya hendaklah pula mendapat perhatian dan bantuan yang nyata dengan berupa tuntutan dan bantuan material dari pemerintah (Poerbakawatja, 1970, hlm. 38).

Usulan tersebut mendapat respons positif dari Menteri PPK. Dalam upaya meningkatkan mutu pendidikan, Pemerintah melalui PPK membentuk Panitia Penyelidik Pengajaran dengan SK Menteri PPK Nomor 104/Bhg.0 tanggal 1 Maret 1946 yang beranggotakan 51 orang dan diketahui oleh Ki Hajar Dewantara. (Hamani, 2004, hlm. 181)

Usaha Panitia Penyelidik

Pengajaran dalam upaya meningkatkan mutu pen-didikan memberikan beberapa usulan. Dalam laporan yang disusun oleh Panitia Penyelidik Pengajaran tanggal 2 Juli 1946 diusulkan bahwa pengajaran agama di-berikan pada jam pelajaran sekolah. untuk tingkat sekolah dasar, pendidikan agama diberikan mulai kelas IV (Rahim, 2001, hlm. 53).

Selain itu, usulan tersebut memuat poin-poin penting dalam pelaksanaan pengajaran agama di sekolah seperti waktu pelaksanaan pengajaran agama, pengangkatan dan gaji guru agama. Kemudian buku yang digunakan untuk pengajaran agama disediakan oleh pemerintah. (Poerbakawatja, 1970, hlm. 41).

Keputusan tersebut ditindaklanjuti dengan diterbitkannya peraturan bersama Menteri Pendidikan Pengajaran dan Kebudayaan dan Menteri Agama Nomor: 1142/Bhg. A (Pengajaran) tanggal 2 Desember 1946 yang berlaku tanggal 1 Januari 1947 dan No. 1285/K. 7 (Agama) Yogyakarta 12-12-1946. Surat Keputusan bersama itu menetapkan bahwa pendidikan Agama diberikan mulai kelas IV sampai dengan kelas VI Sekolah Rakyat. Sedang untuk kelas I, II, dan III Pendidikan Agama tidak boleh diberikan. (Yunus, 1960, hlm. 308)

Khusus untuk mengelola pendidikan agama yang diberikan di sekolah-sekolah umum tersebut, maka pada bulan Desember 1946, dikeluarkanlah Surat Keputusan Bersama (SKB) antara Menteri PP dan K dengan Menteri Agama, yang mengatur pelaksanaan pendidikan agama pada sekolah-sekolah umum (negeri dan swasta), yang berada di bawah Kementerian PP dan $\mathrm{K}$.

Pada tahun 1947 dengan maksud untuk mengatur pelaksanaan dan materi pelajaran Agama di sekolah umum, pemerintah membentuk Majelis Pertimbangan Pengajaran Agama Islam yang dipimpin oleh Ki Hajar Dewantara dari Departemen PPK dan Prof. Abdullah Sigit dari Departemen Agama. (Yunus, 1960, hlm. 308)

Kemudian dilanjutkan dengan keluarnya Undang-Undang Pokok Pendidikan Nomor 4 Tahun 1950 dan Undang-undang Pendidikan Nomor 12 Tahun 1954 Bab XII Pasal 20 tentang pengajaran agama di sekolah-sekolah negeri. berbunyi: 
a. Dalam sekolah-sekolah negeri diadakan pelajaran agama; orang tua murid menetapkan apakah anaknya akan mengikuti pelajaran tersebut.

b. Cara menyelenggarakan pengajaran agama di sekolah-sekolah negeri diatur dalam peraturan yang ditetapkan oleh Menteri Pendidikan Pengajaran dan Kebudayaan bersama-sama dengan Menteri Agama (Poerbakawatja, 1970, hlm. 143).

Penjelasan pasal 20 tersebut berbunyi sebagai berikut:

a. Apakah suatu jenis sekolah memberi pelajaran agama adalah tergantung pada umur dan kecerdasan murid-muridnya.

b. Murid-murid yang sudah dewasa boleh menetapkan ikut atau tidaknya ia dalam pelajaran agama.

c. Sifat pengajaran agama dan jumlah jam pelajaran ditetapkan dalam undang-undang tentang jenis sekolahnya.

d. Pelajaran agama tidak mempengaruhi kenaikan anak. (Poerbakawatja, 1970, hlm. 143)

Pada tahun 1950, pemerintah menyempurnakan rencana pendidikan agama bagi seluruh Indonesia. Langkah yang diambil adalah dengan dibentuknya suatu panitia kerja yang dipimpin oleh Prof. Mahmud Yunus dari Departemen Agama dan Mr. Hadi dari Departemen PPK. Kerja panitia tersebut menghasilkan surat keputusan bersama (SKB) No. 1432/Kab. Tanggal 20 Januari 1951 (Pendidikan) dan No. K.I/651. Tanggal 20 Januari 1951 (Agama), yang berisi rumusan antara lain sebagai berikut (Nizar, 2001, hlm. 349):

a. Pendidikan Agama diberikan mulai kelas IV Sekolah Rakyat.

b. Di daerah-daerah yang agama masyarakatnya kuat, pendidikan agama dapat diberikan mulai dari kelas I Sekolah Rakyat dengan catatan bahwa mutu pengetahuan umum tidak boleh berkurang. c. Di sekolah lanjutan tingkat pertama dan tingkat atas (umum dan kejuruan) diberikan pen-didikan agama dua jam setiap minggu.

d. Pendidikan agama diberikan kepada murid-murid sedikitnya 10 orang dalam satu kelas dan mendapat izin dari orang tua atau walinya.

e. Pengangkatan guru agama, biaya pendidikan agama dan materi pendidikan agama ditanggung oleh Departemen Agama.

Peraturan bersama yang dikeluarkan tanggal 20 Januari 1951 ini sekaligus berfungsi mencabut Penetapan Bersama Menteri Pendidikan Pengajaran dan Kebudayaan dan Menteri Agama tanggal 10 Desember 1946.

Dengan keluarnya peraturan bersama tersebut, maka pendidikan agama secara resmi masuk dalam sekolah-sekolah negeri dan sekolah-sekolah partikelir, mulai dari SR, SMP, sampai ke SMA, dan sekolah-sekolah kejuruan. (Yunus, 1960, hlm. 309)

Untuk menyempurnakan kurikulumnya (rencana pengajaran), Menteri Agama membentuk satu Panitia Perencana Pendidikan Agama Islam di sekolah negeri yang dipimpin oleh KH. Imam Zarkasyi dari Pondok Gontor Ponorogo. Kurikulum tersebut disahkan oleh Menteri Agama pada tahun 1952 setelah beberapa kali mengadakan rapat di Yogyakarta (Yunus, 1960, hlm. 309).

Sebagai bahan lanjutan dari SKB ini, maka pada tanggal 16 Juli 1951 dikeluarkan lagi peraturan bersama dengan nomor surat masing-masing:

No. 17678/Kab. Tanggal 16 Juli 1951 (Pendidikan)

No. K/1/9180 Tanggal 16 Juli 1951 (Agama)

Isi dari peraturan bersama ini adalah memperbaiki peraturan bersama yang dikeluarkan tanggal 20 Januari 1951. Tidak ada perubahan yang prinsipiil pada peraturan yang dikeluarkan tanggal 15 Januari 1951 dengan peraturan berikutnya tanggal 16 Juli 1951, hanya terdapat 
perbaikan pada poin khusus (Daulay, 2007, hlm. 90).

Peraturan bersama tanggal 16 Juli 1951 diiringi dengan keluarnya instruksi pelaksana bersama, tanggal 14 Oktober 1951 dengan nomor surat masing-masing:

No. 36923/Kab. Tanggal 14 Oktober 1952 (Pendidikan)

No. K/I/15773. Tanggal 14 Oktober 1952 (Agama)

Instruksi bersama itu memuat sepuluh pasal meliputi hal yang berkenaan dengan: guru agama, persiapan pengajaran agama di Sekolah Rakyat dan Sekolah Lanjutan, formulir, lingkungan istimewa, pe-ngawasan, tempat latihan beribadat, nilai pengajaran agama, kerja sama dan pengajaran agama di sekolah Partikelir (Sastromidjojo dalam Daulay, 2007, hlm. 91).

Di lingkungan istimewa, pendidikan agama dapat dimulai di kelas I. Yang dimaksud dengan lingkungan istimewa adalah suatu daerah yang kira-kira meliputi satu desa besar di mana penduduknya sangat tebal agamanya. Walikota atau bupati adalah orang yang berhak menyatakan suatu lingkungan sebagai istimewa (Poerbakawatja, 1970, hlm. 145).

SKB tersebut secara yuridis telah menempatkan PAI di sekolah umum memiliki kedudukan yang jelas. Kedudukan pendidikan agama di sekolah umum juga diperkuat karena terakomodir dalam Undang-Undang Pendidikan Nomor 5 Tahun 1950 tentang dasar-dasar Pendidikan dan Pengajaran di Sekolah dan Undang-Undang Nomor 12 Tahun 1954 tentang pernyataan berlakunya UndangUndang Nomor 5 Tahun 1950 di seluruh wilayah Indonesia. Terbitnya undangundang yang mengakomodir keberadaan pendidikan agama Islam di sekolah umum merupakan landasan yang kokoh untuk mengembangkan pendidikan agama Islam. Meskipun demikian, keadaan politik pada awal kemerdekaan yang masih rawan merupakan tantangan berat bagi pendidikan agama Islam di sekolah umum (Hamani, 2004, hlm. 183).
Pada sidang umum MPRS tahun 1966 No. XXVII/MPRS/1966, Pasal 1 menetapkan pendidikan agama menjadi mata pelajaran di sekolah-sekolah mulai dari sekolah dasar sampai universitasuniversitas negeri. (Daulay, 2007, hlm. 91)

TAP MPRS No. XXVII Tahun 1966 ini menyempurnakan TAP MPRS No. II Tahun 1960 dengan menghapus kata-kata "dengan pengertian bahwa murid-murid berhak untuk tidak ikut serta apabila wali murid/murid dewasa menyatakan keberatannya". Ketetapan MPRS No. XXVII Tahun 1966 ini merupakan kebijakan yang menjadi dasar dalam menetapkan bahwa pendidikan agama diberikan di sekolah negeri seperti yang dinyatakan undang-undang sistem pendidikan berikutnya. (Djamas, 2009, hlm. 128)

Penetapan-penetapan ini semuanya semakin mengukuhkan status dan kedudukan pendidikan agama di sekolahsekolah umum. Dengan demikian maka sejak tahun 1966 pendidikan agama menjadi hak wajib para siswa mulai dari Sekolah Dasar sampai Perguruan Tinggi Umum Negeri di seluruh Indonesia.

\section{KESIMPULAN}

Berdasarkan hasil penelitian yang berjudul "Sejarah Pendidikan Agama Islam di Sekolah Dasar tahun 1945-1966”, dapat disimpulkan beberapa hal.

Pertama, pendidikan Indonesia setelah kemerdekaan mengalami perubahan. Pemerintah ingin membuat sistem pendidikan nasional yang sesuai dengan keadaan rakyat Indonesia. Hal itu dengan dibahasnya landasan, tujuan, dan segala macam hal yang menyangkut perubahan sistem pendidikan demi tercapainya citacita pembangunan Indonesia yang lebih baik.

Kedua, dimasukkannya PAI dalam kurikulum nasional dirasakan penting sebagai dari perubahan dalam sistem kenegaraan yang dinyatakan dalam Undang-Undang Dasar 1945 dan Pancasila 
yang dengan jelas menyebutkan bahwa negara Indonesia berdasarkan Ketuhanan Yang Maha Esa dan bagi setiap warga negara berhak memeluk agama yang diyakininya masing-masing.

Ketiga, perkembangan Pendidikan Agama setelah dimasukkan dalam kurikulum pengajaran dalam rentang tahun 1946-1966 memperlihatkan perubahan yang lebih signifikan. Meskipun pada awal dimasukkannya Pendidikan Agama hanya bersifat opsional.

\section{REFERENSI}

Ahmadi, S. (2003). Kapita Selekta Pendidikan Islam. Bandung: Penerbit Angkasa.

Alwasilah, A. C. (2009). Pokoknya Kualitatif. Jakarta: PT. Dunia Pustaka Jaya.

Arikunto, S. (2010). Prosedur Penelitian: Suatu Pendekatan Praktik. Jakarta: PT. Rineka Cipta.

Ashari, A. (2015, Maret 31). SEJARAH PAI DI INDONESIA SEJAK ORDE LAMA, ORDE BARU, HINGGA ERA REFORMASI. [Online]. Diakses dari http://paiskabtng.blogspot.com/201 4/08/sejarah-pai-di-indonesia-sejakorde.html

Daulay, H. P. (2007). Sejarah Pertumbuhan dan Pembaruan Pendidikan Islam di Indonesia. Jakarta: KENCANA.

Djamas, N. (2009). Dinamika Pendidikan Islam di Indonesia Pascakemerdekaan. Jakarta: Rajawali Press.

Djojonegoro, I. W. (1996). Lima Puluh Tahun Perkembangan Pendidikan Indonesia. Jakarta: Badan Penelitian dan Pengembangan Pendidikan dan Kebudayaan, Depdikbud.

Djumhur, I. (1976). Sejarah Pendidikan. Bandung: CV Ilmu.
Hamani, T. (2004). Pendidikan Agama Islam di Sekolah Umum Sebagai Keharusan Sejarah. Jurnal Pendidikan Agama Islam Vol. 1, No. 2, 171-191.

Ismaun. (2005). Pengantar Sejarah Sebagai Ilmu dan Wahana Pendidikan. Bandung: Historia Utama Press.

Nizar, S. (2009). Sejarah Pendidikan Islam: Menelusuri Jejak Sejarah Pendidikan Era Rasulullah Sampai Indonesia. Jakarta: Kencana.

Poerbakawatja, S. (1970). Pendidikan Dalam Alam Indonesia Merdeka. Jakarta: P.T. GUNUNG AGUNG.

Purwanto. (2007). Instrumen Penelitian Sosial dan Pendidikan. Yogyakarta: Pustaka Belajar.

Putra, N., \& Lisnawati, S. (2012). Peneltian Pendidikan Agama Islam. Bandung: PT Remaja Rosdakarya.

Rahim, H. (2001). Arah Baru Pendidikan Islam di Indonesia. Jakarta: PT Logos Wacana Ilmu.

Sarwono, J. (2006). Metode Penelitian Kuantitatif dan Kualitatif. Yogyakarta: Graha Ilmu.

Sugiyono. (2011). Metode Penelitian Kombinasi (Mixed Methods). Bandung: Alfabeta.

Sukardi. (2004). Metode Penelitian Pendidikan. Jakarta: PT Bumi Aksara.

Yunus, M. (1960). Sejarah Pendidikan Islam di Indonesia. Jakarta: Pustaka Mahmudiah.

Zuhairini. (2008). Filsafat Pendidikan Islam. Jakarta: Bumi Aksara. 